Proc. Indian Acad. Sci. (Earth Planet. Sci.), Vol. 93, No. 2, July 1984, pp. 105-110.

(C) Printed in India.

\title{
Zonal winds and temperature structure at the upper levels during poor and good monsoon
}

\author{
L S HINGANE \\ Indian Institute of Tropical Meteorology, Pune 411005 , India \\ MS received 7 July 1983; revised 28 May 1984
}

\begin{abstract}
Global analyses of zonal wind field and thermal field structure at standard pressure levels of 200,150 and $100 \mathrm{mb}$ have been carried out in India during July 1979-a poor monsoon year and July 1975-a good monsoon year. More than 250 stations in the belt $60^{\circ} \mathrm{N}$ and $60^{\circ} \mathrm{S}$ were selected. Contrasting features of the zonal wind field structure and thermal field are brought out, and it is shown that monsoon activity is reflected in the upper level and is controlled by planetary scale.
\end{abstract}

Keywords. Zonal winds; temperature structure; monsoon.

\section{Introduction}

During recent years, studies associating the upper level temperature and wind fields with the performance of southwest monsoon have been made (Ananthakrishnan and Ramakrishnan 1964). Prakash Rao (1975) noted the strengthening of the upper tropospheric easterlies over India during break monsoon and drought monsoon period. Kanamitsu and Krishnamurti (1979) analysed the wind field structure for good monsoon year 1967 and showed the spreading of easterly winds were more during normal monsoon year than drought monsoon years. Keshawamurty and Awade (1974), studied the dynamical abnormalities associated with drought in the Asiatic summer monsoon and showed that the main abnormality in the thermal field is that temperatures are considerably below normal over southern part of USSR, Iran, Afganistan and north India. Verma (1980) observed cooling of the upper troposphere over north India during drought monsoon years.

The present study aims at furtherr examining the structure of the upper tropospheric temperature and wind fields during weak and active monsoon periods. A systematic analysis of the zonal component and thermal field structure is presented for July 1979 a drought monsoon year (rainfall $23 \%$ below normal) and July 1975-a good monsoon year (rainfall $16 \%$ above the normal). The data used are the monthly mean value of wind and temperature and were taken from wMo $(1975,1979)$. The location of the stations selected for this analysis is shown in figure 1.

\section{Analysis of zonal wind field}

\section{$2.1 \quad 100 \mathrm{mb}$}

Figures 2 and 3 give the distribution of easterly and westerly wind fields in July 1979 and July 1975 respectively in the region between $60^{\circ} \mathrm{N}$ and $60^{\circ} \mathrm{S}$ over the whole globe. The following important features of the anlysis are seen. 


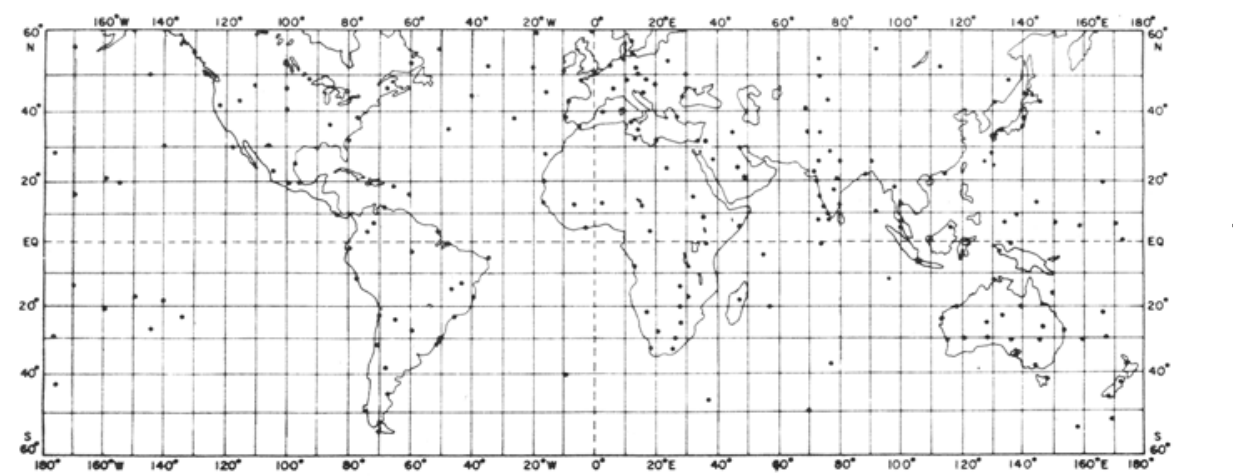

Figure 1. Location of study stations.

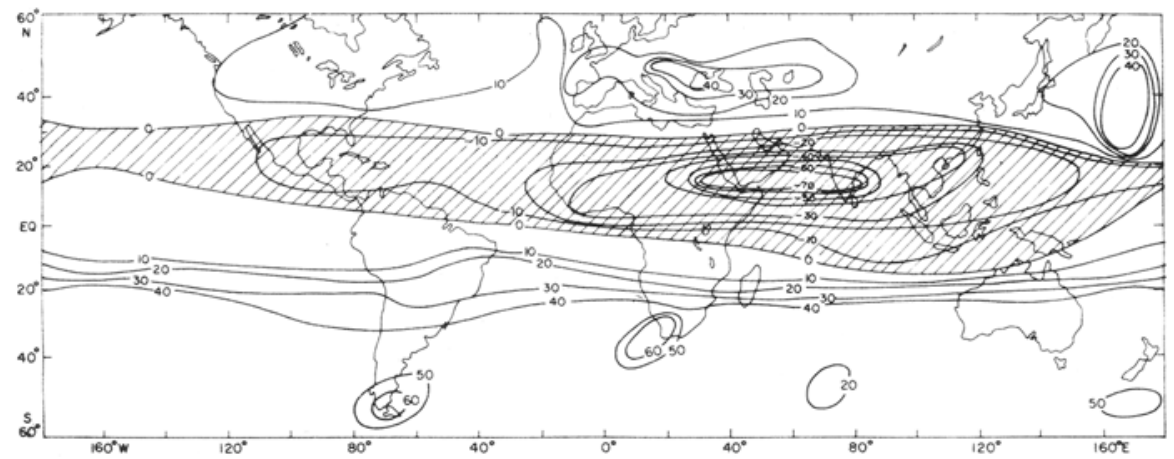

Figure 2. July 1979: Zonal wind field at $\left.100 \mathrm{mb}^{(\mathrm{m} \mathrm{sec}}{ }^{-1}\right)$.

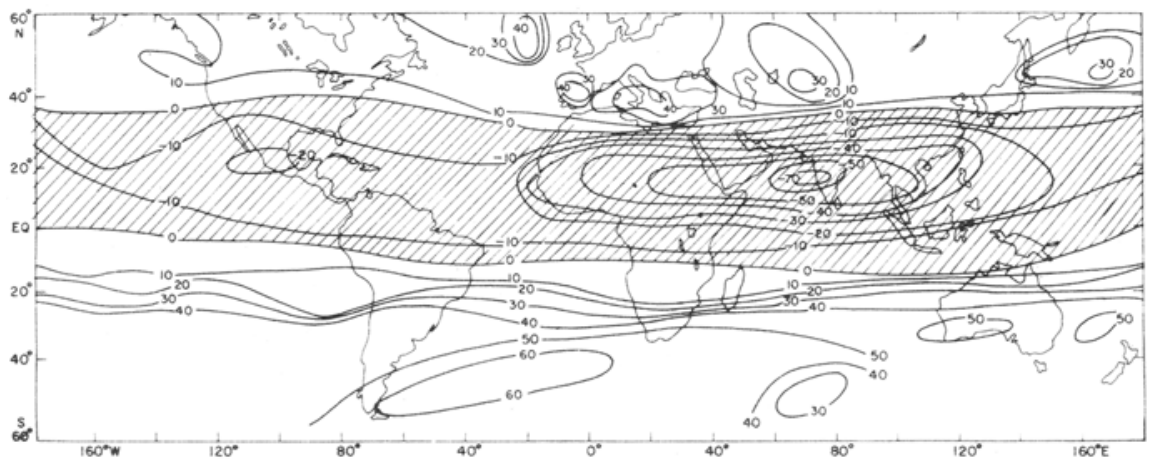

Figure 3. July 1975: Zonal wind field at $\left.100 \mathrm{mb}^{(\mathrm{m} \mathrm{sec}}{ }^{-1}\right)$.

2.1a Extension: Extension of easterly wind field differs significantly in these 2 yr. During July 1975 its latitudinal extension is more than that during July 1979. Easterlies extend over Asian latitudes even in extratropical region during July 1975 whereas in July 1979 easterlies are seen only in the tropical region. Easterly extent over America, Atlantic and Pacific region is also greater during 1975 than during 1979. 
2.1b Speed: Speed of the easterly winds also differs significantly. In the tropical region easterlies are stronger during 1979 than during 1975. TEJ extended from Bangkok (Thailand), Madras (India) to Khartoum (Sudan) in 1979 whereas in 1975 it was observed only over the Peninsular region of India.

\section{$2.2200 \mathrm{mb}$}

Figures 4 and 5 show the zonal wind field at $200 \mathrm{mb}$ for the $2 \mathrm{yr}$. It is seen that the extension of easterly and westerly flow for the $2 \mathrm{yr}$ does not differ significantly. However, variation in the strength of the $U$ component over some region in the subtropical belt is observed. Speed of westerlies over Australia and Japan show very interesting contrast. Over Australia westerly wind flow is stronger during July 1975 as compared to that in July 1979 whereas over Japan it is weaker during July 1975 as compared to that in July 1979.

In the analysis of tropical circulations during drought and normal rainfall months, Kanamitsu and Krishnamurti (1978, figure 2) found that easterlies in 1967 (normal monsoon year) occupied more of the tropics than in 1972. Our results show that not only easterlies occupy more tropics but extend into the extratropical region over Asian latitudes during flood monsoon year. These results agree with that of Kanamitsu and

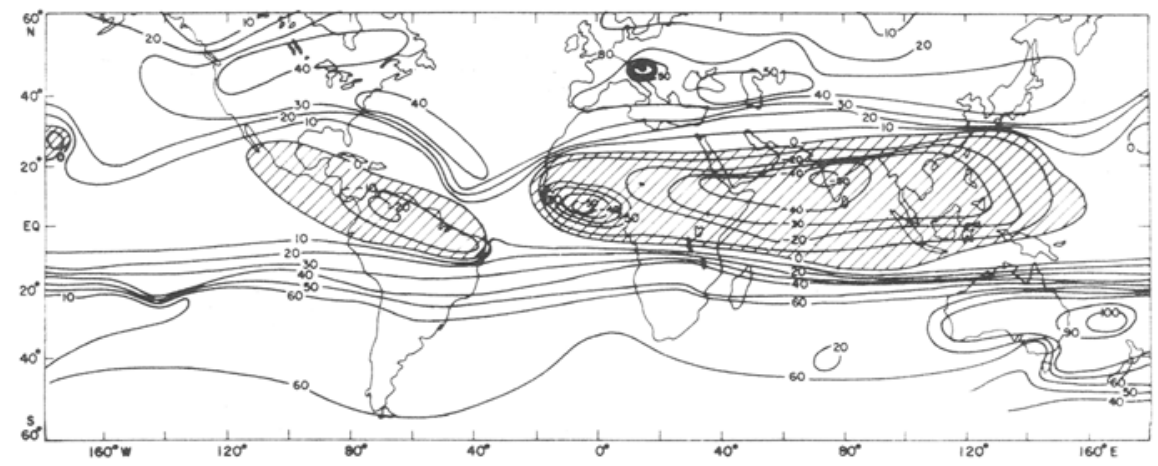

Figure 4. July 1979: Zonal wind field at $200 \mathrm{mb}\left(\mathrm{m} \mathrm{sec}^{-1}\right)$.

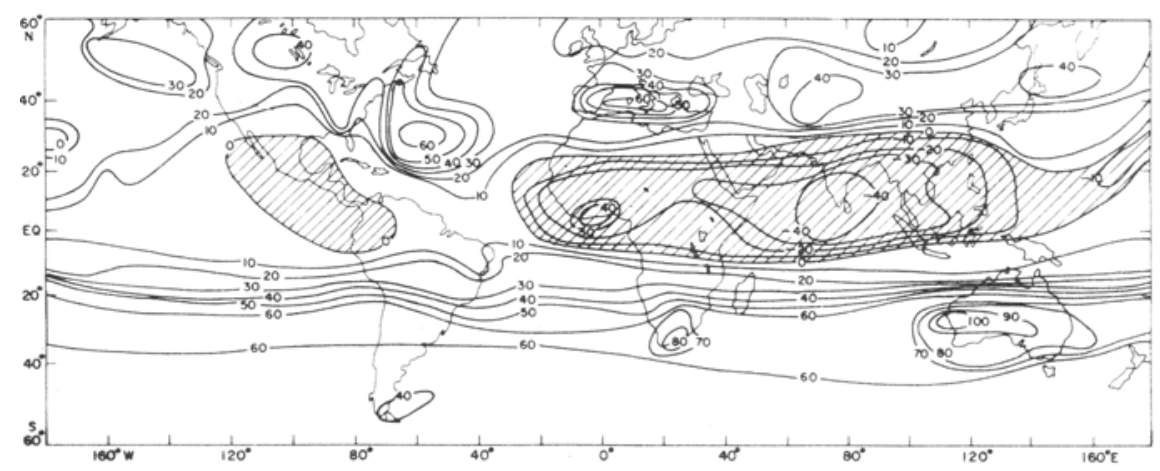

Figure 5. July 1975: Zonal wind field at $\left.200 \mathrm{mb}^{(\mathrm{m} \mathrm{sec}}{ }^{-1}\right)$. 
Krishnamurti (1978). Further their analysis shows that the intensity of TE is greater during normal monsoon year than during drought year whereas our results are contrary to this and show that the intensity of TEJ is more during the drought year than that during flood monsoon year. Ananthakrishnan and Ramakrishnan (1964) and Prakash Rao (1975) noticed the strengthening of easterlies during break monsoon which supports our results.

\section{Thermal structure}

Figures 6 and 7 show the temperature field at $100 \mathrm{mb}$ during July 1979 and July 1975 whereas figures 8 and 9 show the temperature during July 1979 and July 1975 at $200 \mathrm{mb}$ level. Remarkable variations are observed in the thermal structure over India especially over north and middle India temperature during good monsoon year (1975) and drought monsoon year (1979) and this difference is observed at both levels. These figures show that during good monsoon year temperature in the upper troposphere was higher as compared to those during the drought year.

A reverse picture is seen at $200 \mathrm{mb}$ over middle and south of Japan, Australia, south of North America and over north-west and south-west Pacific. Temperature was low in

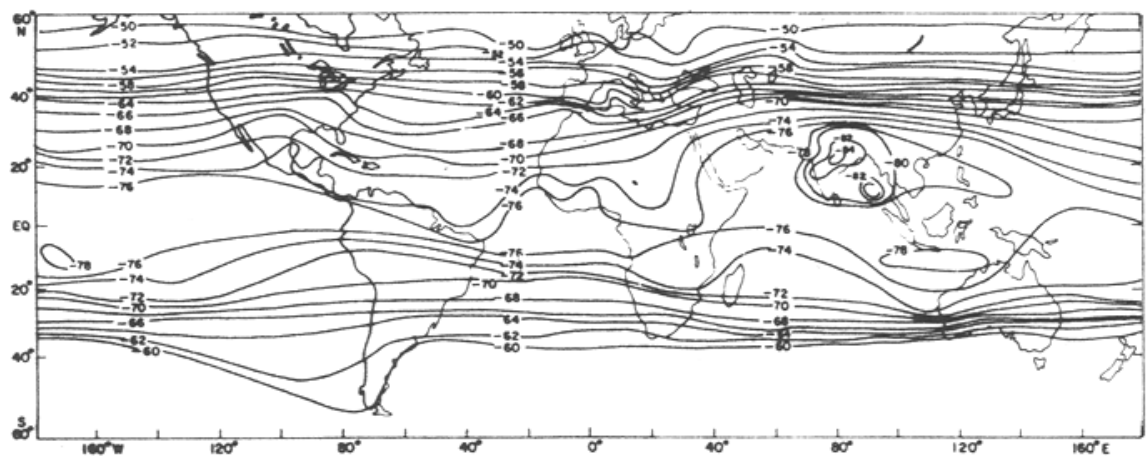

Figure 6. July 1979: Temperature field at $100 \mathrm{mb}\left({ }^{\circ} \mathrm{C}\right)$.

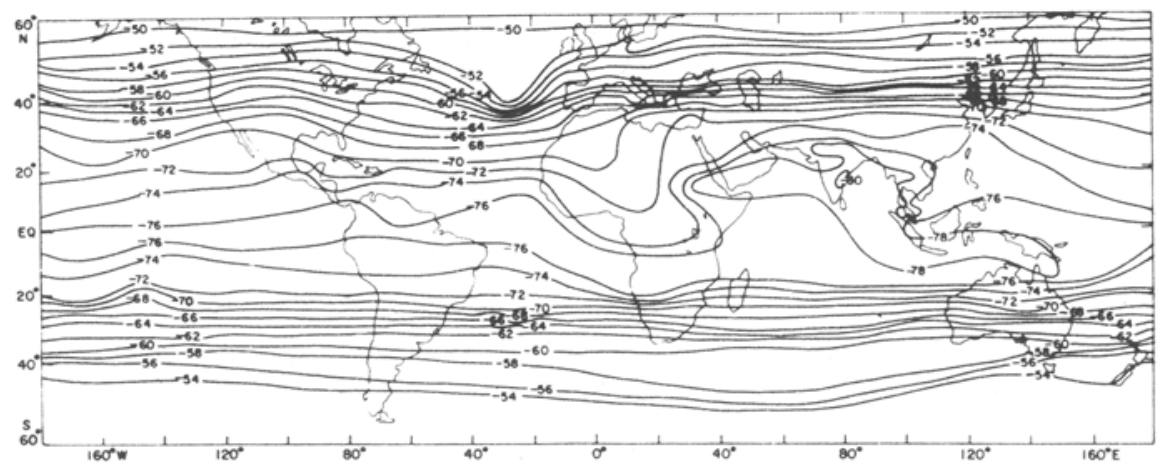

Figure 7. July 1975: Temperature field at $100 \mathrm{mb}\left({ }^{\circ} \mathrm{C}\right)$. 


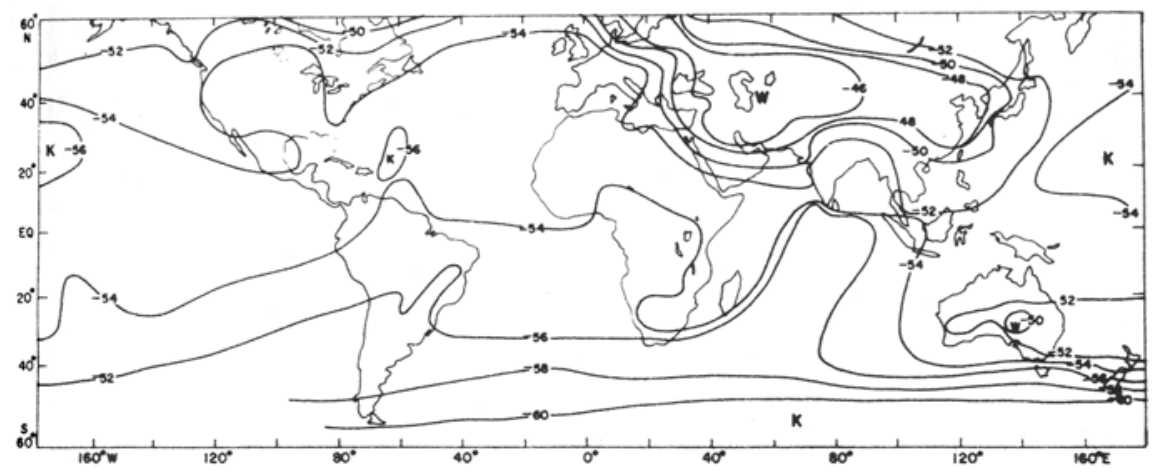

Figure 8. July 1979: Temperature field at $200 \mathrm{mb}\left({ }^{\circ} \mathrm{C}\right)$.

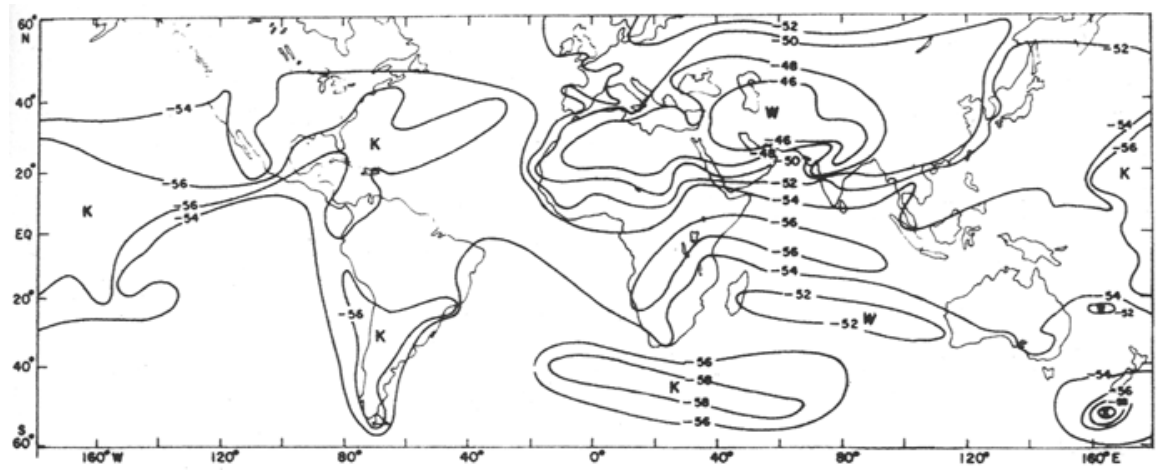

Figure 9. July 1975: Temperature field at $200 \mathrm{mb}\left({ }^{\circ} \mathrm{C}\right)$.

July 1975 than in July 1979. But this contrast is not as intense as is observed over India.

Verma (1980) analysed the upper air thermal field at some selected stations over the Indian continent from 1967 to 1977 and observed cooling of the upper troposphere over north India during the pre-monsoon period April-May and these anomalies generally persist through the subsequent monsoon months of June, July and August. Verma indicated that this has a link with the below-normal rainfall activity. Our results also agree with this finding.

\section{Conclusion}

Our upper air analysis at standard pressure levels 200,150 and $100 \mathrm{mb}$ of zonal wind field and thermal field for the drought and good monsoon years leads us to arrive at the following conclusions. Monsoon activities are well reflected in the upper air and these activities are also controlled by planetary scale. Drought/good monsoon is well associated with lower/higher spreading of easterlies near tropopause all over the globe in the low latitudes. From the present analysis it appears that the cooler/warmer temperature in the upper troposphere over north and middle Indian continental area are associated with drought/good monsoon conditions. However, in the above 
preliminary study we have examined the field only for the month of July for two contrasting years. For better appreciation of the results it would be worthwhile to examine the upper air wind and thermal fields for many consecutive years during all pre-monsoon and monsoon months.

\section{Acknowledgement}

The author thanks P V Joseph, Director, Training India Meteorological Department, Pune for suggesting this work and Dr P C Joshi for stimulating discussions. The author also acknowledges Shri H N Bhalme, and Dr G B Pant for encouragement. Thanks are due to Shri S D Patil, and Mrs S P Lakade for assistance.

\section{References}

Ananthakrishnan R and Ramakrishnan A R 1964 Proc. Symp. Trop. Meteorol. New Zealand 144 Kanamitsu M and Krishnamurti T N 1978 Mon. Weath. Rev. 106331

Keshawamurty R N and Awade S T 1974 Indian J. Meteorol. Hydrol. Geophys. 25257

Prakash Rao G S 1975 Indian J. Meteorol. Hydrol. Geophys. 26535

Verma R K 1980 Mon. Weath. Rev. 1081072

WMO-Monthly climatic data for the World, July 1975 and July 1979 